\title{
EQUINE HETEROTOPIC POLYODONTIA: A CASE REPORT
}

\author{
Camila Angela Marques ${ }^{1}$ \\ Karolliny Merlo Goehringer ${ }^{1}$ \\ Halana do Carmo Silva ${ }^{2}$ \\ Alvaro de Paula Lage de Oliveira ${ }^{3 *}$ \\ Mayra Cunha Flecher ${ }^{3}$ \\ Otavio Luiz Fidelis Junior ${ }^{3}$ \\ Odael Spadeto Junior ${ }^{3}$ \\ Tiago Facury Moreira ${ }^{4}$
}

MARQUES, C. A.; GOEHRINGER, K. M.; SILVA, H. do C.; OLIVEIRA, A. de P. L.; FLECHER, M. C.; FIDELIS JUNIOR, O. L.; SPADETO JUNIOR, O.; MOREIRA, T. F. Equine heterotopic polyodontia: a case report. Arquivos de Ciências Veterinárias e Zoologia da UNIPAR, Umuarama, v. 23, n. 2cont., e2313, 2020.

\begin{abstract}
Heterotopic polyodontia have been described in most domestic species. Known as a dentigerous cyst but appropriately called heterotopic polyiodontics, it rarely occurs in horses, however it is easily recognized as a congenital defect. The cysts usually associated with this condition contain part or all of dental structures. The heterotopic tooth or dental structure is usually adhered to the temporal bone and surrounded by a secretory membrane, with a accumulation of exudate and draining tract along the proximal pinna or directly over the cyst. This case report describes in a 2.5 -year-old female quarter horse, weighing $430 \mathrm{~kg}$, with a heterotopic polyodontia that contained two easily small's identifiable dental structures, presented for evaluation of a chronic intermittent mucopurulent exudate discharge from the right sub-auricular region in the mastoid process of the temporal bone and a drainage tract near the right pinna. The diagnosis is established with clinical, radiographic, ultrasound and confirmed by histopathological examination of the structures removed. The cystic capsule was surgically removed, measuring approximately $3.0 \times 2.3 \mathrm{~cm}$ in diameter, filled with mucopurulent exudate and containing two dental structures within $0.5 \mathrm{~cm}$ in diameter and $0.2 \mathrm{~cm}$ in diameter. Microscopic examination revealed a cystic area covered by stratified squamous epithelium with a lympho-histio-plasmatic cell infiltrate in the dermis, which was compatible with heterotopic polyodontia. Postoperatively, there were no neuromotor sequelae and wound healing evolved positively.
\end{abstract}

KEYWORDS: Congenital. Dentigerous cyst. Ectopic teeth. Odontogenic cyst.

\section{POLIODONTIA HETEROTÓPICA EQUINA: RELATO DE CASO}

RESUMO: A poliodontia heterotópica tem sido descrita na maioria das espécies domésticas. Conhecido como cisto dentígero, mas apropriadamente denominado poliodontia heterotópica, raramente ocorre em equinos, porém é facilmente reconhecido como defeito congênito. Os cistos geralmente associados a essa condição contêm parte ou toda as estruturas dentarias. $\mathrm{O}$ dente heterotópico ou estrutura dentaria é comumente encontrado aderido ao osso temporal e envolvido por uma membrana secretora, com acúmulo de exsudato e trajeto de drenagem ao longo do pavilhão auricular proximal ou diretamente sobre o cisto. Este relato descreve um caso de em um equino,fêmea, quarto de milha, com 2,5 anos de idade, pesando $430 \mathrm{~kg}$, com poliodontia heterotópica que continha duas estruturas dentarias facilmente indentificadas, apresentando um orifício na região sub-auricular direita no processo mastóideo do osso temporal, com secreção mucopurulenta intermitente e crônica, próximo ao pavilhão auricular direito. O diagnóstico foi estabelecido com exame clínico, radiográfico, ultrassonográfico e confirmado pelo exame histopatológico das estruturas retiradas. A cápsula cística foi removida cirurgicamente medindo aproximadamente $3,0 \times 2,3 \mathrm{~cm}$ de diâmetro, preenchida com exsudato mucopurulento e contendo em seu interior duas estruturas dentárias medindo cerca de $0,5 \mathrm{~cm}$ de diâmetro e $0,2 \mathrm{~cm}$ de diâmetro. $\mathrm{O}$ exame microscópico revelou área cística revestida por epitélio escamoso estratificado com infiltrado linfo-histo-plasmocitário na derme, compatível com poliodontia heterotópica. No pós-operatório não houve sequelas neuromotoras e a cicatrização da ferida evoluiu positivamente.

PALAVRAS-CHAVE: Congênito. Cisto dentígero. Cisto odontogênico. Dente ectópico.

\section{POLIODONTIA HETEROTÓPICA EQUINA: RELATO DE CASO}

RESUMEN: La poliodontia heterotópica ha sido descrita en la mayoría de las especies domésticas. Conocido como quiste dentígero, pero apropiadamente llamado poliodontia heterotópica, raramente ocurre en equinos, sin embargo se reconoce fácilmente como un defecto congénito. Los quistes generalmente asociados a esa condición contienen parte o la totalidad de las estructuras dentales. El diente heterotópico o estructura dental se encuentra comúnmente adherido al hueso temporal y rodeado por una membrana secretora, con acumulación de exudado y vía de drenaje a lo largo del pabellón auricular proximal o directamente sobre el quiste. En este informe se describe el caso de una hembra, cuarto de milla, de 2,5 años de edad,

DOI: 10.25110 /arqvet.v23i2cont.2020.8148

${ }^{1}$ Resident in clinic, surgery and anesthesiology of large animals at Vila Velha University, Vila Velha, Espírito Santo, Brazil.

${ }^{2}$ Resident in pathology at Vila Velha University, Vila Velha, Espírito Santo, Brazil.

${ }^{3}$ Teaching of the course of Veterinary Medicine at Vila Velha University, Vila Velha, Espírito Santo, Brazil.

${ }^{4}$ Teaching of the course of Veterinary Medicine at Federal of Minas Gerais University, Minas Gerais, Brazil.

*Correspondence: oliveira.medvet@hotmail.com 
con $430 \mathrm{~kg}$ de peso, presentando poliodontia heterotópica que contenía dos estructuras dentales fácilmente identificables, con un orificio en la región subauricular derecha en el proceso mastoides del hueso temporal, secreción mucopurulenta intermitente y crónica próximo al oído derecho. El diagnóstico se estableció con examen clínico, radiográfico, ecográfico y se confirmó con el examen histopatológico de las estructuras extirpadas. La cápsula quística se extrajo quirúrgicamente midiendo aproximadamente $3,0 \times 2,3 \mathrm{~cm}$ de diámetro, rellena con exudado mucopurulento y conteniendo en su interior dos estructuras dentales que medían aproximadamente $0,5 \mathrm{~cm}$ de diámetro y $0,2 \mathrm{~cm}$ de diámetro. El examen microscópico reveló una zona quística cubierta por un epitelio escamoso estratificado con infiltrado linfo-histo-plasmocítico en la dermis, compatible con poliodontia heterotópica. En el postoperatorio no se produjeron secuelas neuromotoras y la cicatrización de la herida evolucionó positivamente.

PALABRAS CLAVE: Congénito. Quiste dentígero. Quiste odontogénico. Diente ectópico.

\section{Introduction}

Heterotopic polyodontia, also known as a dentigerous cyst, ectopic teeth, periauricular cyst, or ear tooth (GARDNER, 1993) is a benign and congenital abnormality resulting from the retention of odontogenic epithelial cells from the crown of an unerupted tooth (JENA et al., 2004). According to Fessler (1998) and Uzal, Plattner and Hostetter (2016) it occurs due to the delay in closure of the first branchial slit during embryogenesis, with migration and inclusion of ectopic tooth tissue that developed from enamelforming cells (SANTANA; REBELLATO; MACHADO, 2012).

Usually the lesion is unilateral, occurs in young horses, is located mainly near the ear auricle, and may or may not adhere to the temporal bone (DI FILIPO et al., 2004; PEIXOTO et al., 2016; ROCHA et al., 2014). Clinically, this lesion is composed of different amounts of dental tissue within a cystic structure with swelling but no pain sensitivity to palpation. It had a fluctuating or firm consistency along with the presence of a fistula that drained mucous content (PEIXOTO et al., 2016; PENSE; WILEWSKI, 2002).

Diagnosis can be made through clinical recognition, based on the location and typical characteristics of heterotopic polyodontia observed with x-ray and ultrasound examination (PEIXOTO et al., 2016). However, definitive diagnosis can only be made after histopathological examination of the removed cyst (EASLEY; FRANKLIN; ADAMS, 2010; JUBB; KENNEDY, 2007).

Therapeutic success is achieved through surgical treatment, which consists of the resection of all dental and cystic epithelial elements (DI FILIPO et al., 2004). These dental elements are loosely attached to the soft tissue of the cystic wall or firmly adhere to the temporal bone (GAUGHAN; DEBOWES, 1993). According to Di Filippo et al. (2004) precaution is required during surgery to prevent temporal bone fracture and regional neurovascular injuries. The present study reports a case of unilateral heterotopic polyodontia in a horse, which was located in the sub-auricular region in the mastoid process of the temporal bone.

\section{Case report}

A 2.5-year-old, female brown Quarter Horse, weighing $430 \mathrm{~kg}$ was referred to the Professor Alexandre Hippler Veterinary Hospital at Vila Velha University (UVV), preseting a chronic fistula (six months of evolution) with mucopurulent exudate in the right sub-auricular region (Figure 2A). Before referral to the Veterinary Hospital, the animal was treated by a field veterinarian who prescribed a treatment with gentamicin and ceftiofur for seven days a few times during the evolution period of the disease. During use of the medication, the mucopurulent exudate subsided, but after the end of antibiotic therapy the secretion recurred, showing a lack of satisfactory response to the treatment. In the general physical examination, the animal presented a heart rate of $40 \mathrm{bpm}$, a respiratory rate of $18 \mathrm{bpm}$ and body temperature of $37.9^{\circ} \mathrm{C}$. Specific physical examination revealed that the horse had a slight swelling located in the right sub-auricular region in the mastoid process of the temporal bone, with no pain sensitivity to palpation. The swelling had a floating consistency and had a fistula with discharge of mucopurulent exudate. All physiological parameters remained within the normal range for the species and no dental alterations were found during inspection of the oral cavity.

Blood count and biochemical examinations showed no alterations. Ultrasound ${ }^{5}$ of the transcutaneous acoustic window of the right temporal region, performed with a 10 $\mathrm{MHz}$ linear frequency transducer, showed a cystic area measuring $1.21 \times 1.02 \mathrm{~cm}$, presenting a hypoechogenic area with a hyperechogenic structure in its center (Figure 1A). Radiographic $^{6}$ examination through rostrocaudal oblique projection revealed the presence of two radiopaque structures located near the animal's right temporal bone (Figure 1B).

Figure 1 - Ultrasound imaging of the right temporal region: transcutaneous acoustic window showing a cystic structure (arrow) generated with a $10 \mathrm{MHz}$ frequency linear transducer demonstrating a circumscribed area with the presence of hypoechogenic fluid (measuring $1.21 \times 1.02 \mathrm{~cm}$ in length) and with a hyperechogenic structure in its center (asterisk) (A). Rostrocaudal oblique cranial X-ray projection showing two radiopaque rounded dental structures located near the animal's right temporal bone (circle) (B).

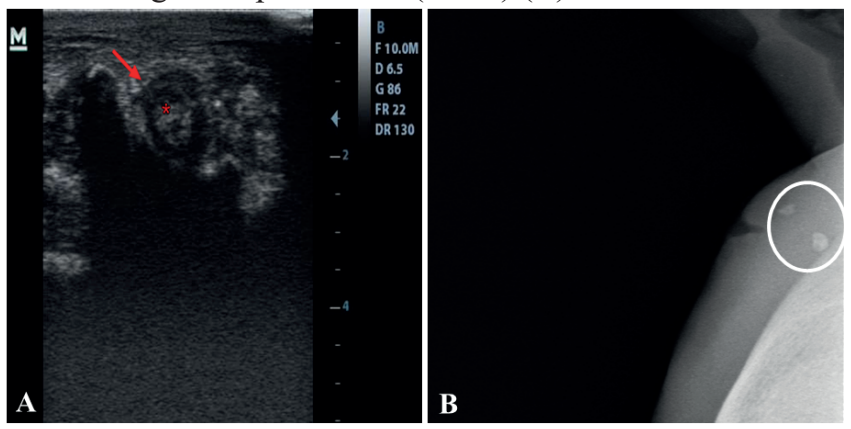

Source: Personal collection.

${ }^{5}$ Ultrassom Veterinário DP-10 Vet Power Mindray, Mindray, Monções, SPBrasil.

${ }^{6}$ Raio-X Portátil EPX-Série CE e FDA, Ecotron Co., Ltd, Seoul, South Korea. 
The animal was submitted to general intravenous anesthesia for the field surgical procedure. Sedation was performed with $10 \%$ xylazine $^{7}$ at $0.7 \mathrm{mg} / \mathrm{kg}$ and induction with $10 \%$ ketamine $^{8}$ at $2 \mathrm{mg} / \mathrm{kg}$ and diazepan ${ }^{9}$ at $0.1 \mathrm{mg} /$ $\mathrm{kg}$. After placing him in the right lateral position, anesthetic maintenance was performed with Triple Drip solution $\left(10 \%\right.$ glyceryl guaiacol ether ${ }^{10}, 10 \%$ xylazine at $1 \mathrm{mg}$ / $\mathrm{kg}$ dose and 10\% ketamine at $2 \mathrm{mg} / \mathrm{kg}$ dose). Local subcutaneous infiltrative anesthesia under the incision line and auriculopalpebral nerve was blocked using lidocaine ${ }^{11}$ with no vasoconstrictor. During surgery, two skin incisions were made, a transverse and a horizontal, and the subcutaneous connective tissue was exposed, making visible the fibrous capsule of the cyst (Figure 2B). With the help of Metzembaum scissors, all tissue around the cyst was then completely removed. The surgical wound was kept open for healing to occur. The animal recovered well from anesthesia and had no neuromotor sequelae, showing that there were no nerve involvements during the surgical procedure. The cyst (approximately $3.0 \times 2.3 \mathrm{~cm}$ ) was sectioned and had a solid structure inside measuring about $0.5 \mathrm{~cm}$ in diameter and another fragment measuring $0,2 \mathrm{~cm}$ in diameter. All materials were sent for histopathological examination (Figure 2C).

Figure 2 - Fistula with mucopurulent exudate in the right sub-auricular region in the mastoid process of the temporal bone (circle) (A). Surgical excision in the right sub-auricular region: dissection of the fistulous tract (asterisk) (B) and cystic membrane (circle) (B). Sectioned cystic membrane of approximately $3.0 \times 2.3 \mathrm{~cm}$, showing a dental fragment inside measuring about $0.5 \mathrm{~cm}$ in diameter (arrow). Adjacent to that is a cystic area, circumscribed and lined with haircoated skin (asterisk) (C).
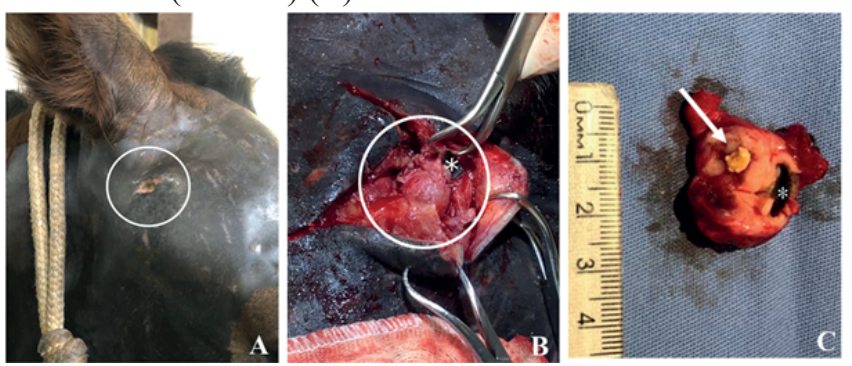

Source: Personal collection

Postoperative treatment consisted of antimicrobial therapy with ceftiofur ${ }^{12} \quad(2 \mathrm{mg} / \mathrm{kg})$ intravenously for seven days, non-steroidal anti-inflammatory therapy $2 \%$ meloxicam $^{13}(0.6 \mathrm{mg} / \mathrm{kg})$ intravenously for five days, local dressing twice a day (daily), cleaning with $4 \%$ chlorhexide $^{14}$ base and a topical application of a neomycin ${ }^{15}$ based antiseptic ointment. Healing progressed well and 16 days

\footnotetext{
${ }^{7}$ Xilazina 10\%, Cristalia Produtos Químicos Farmacêuticos LTDA, Itapira-SP. ${ }^{8}$ Cetamina $10 \%$,CristaliaProdutos QuímicosFarmacêuticosLTDA,Itapira-SP. ${ }^{9}$ Diazepam, Cristalia Produtos Químicos Farmacêuticos LTDA, Itapira- SP. ${ }^{10}$ Éter Gliceril Guaiacol, Cristalia Produtos Químicos Farmacêuticos LTDA, Itapira- SP.

${ }^{11}$ Cloridrato de Lidocaína 2\%, Cristalia Produtos Químicos Farmacêuticos LTDA, Itapira- SP.

${ }^{12}$ Minoxel 8G, L.P.S. Agrofarma LTDA, Mogi Mirim- SP.

${ }^{13}$ Meloxicam 2\%, Agrofarma LTDA, Mogi Mirim- SP.

${ }^{14}$ Clorexidina 4\%, Global Distribuição e Representação, Vila Velha - ES.

${ }^{15}$ Sulfato de Neomicina, Cristalia Produtos Quimicos Farmacêuticos LTDA, Itapira- SP.
}

post the surgical procedure the lesion had almost healed.

The histopathological examination of the removed tissue presented two cystic areas, an area covered by stratified squamous epithelium with associated cutaneous appendages, mainly sebaceous glands and a cystic area, also lined with stratified squamous epithelium, however with no associated cutaneous appendages, showing an accentuated diffused mononuclear lympho-histio-plasmacytic inflammatory infiltrate in the superficial dermis around the cyst (Figure 3), which was compatible with heterotopic polyodontia.

Figure 3 - Photomicrograph of the removed cystic membrane showing a fragment consisting of two cystic areas: an area covered by stratified squamous epithelium, with associated cutaneous appendages, mainly sebaceous glands (indicated with an asterisk) in $4 \mathrm{X}$ objective (A). The other cystic area also lined with stratified squamous epithelium, but without associated cutaneous appendages, presenting a diffused mononuclear lympho-histio-plasmacytic inflammatory infiltrate accentuated in the superficial dermis (indicated by arrow) around the cyst in $10 \mathrm{X}$ objective (B).

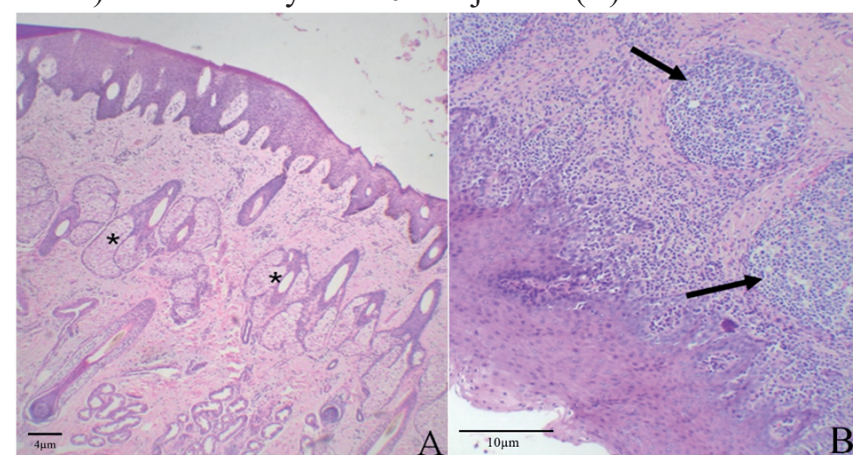

Source: Personal collection.

\section{Discussion}

Heterotopic polyodontia is a type of developmental odontogenic cyst resulting from a failure in the closure of the first branchial slit with displacement towards the temporal region and inclusion of ectopic dental tissue (FESSLER, 1988; GAUGHAN; DEBOWES, 1993; SANTANA; REBELLATO; MACHADO, 2012). In veterinary medicine, it has been reported in dogs, pigs, sheep and horses (BAXTER, 2004; PEIXOTO et al., 2016; ROCHA et al., 2014; THATCHER, 2017). In horses, Gardner (1993) assumes that this lesion may be associated with vestigial wolf teeth, which refer to rudimentary premolars.

Growth of the cystic structure in heterotopic polyodontia is, in most cases, slow and usually affects horses in their early life (PEIXOTO et al., 2016; ROCHA et al., 2014). This is similar to the observation in the present study, in which the horse was two and a half years old and the evolution of cystic growth was approximately six months. However, several isolated cases in older horses have been reported such as by McClure et al. (1993) who described a case of a 14-year-old mare and by Prado et al. (2017) who described it in a 20- year-old horse.

The clinical findings of the present case are compatible with those described in previous literature. It was clinically characterized by the presence of dental structure enclosed in a secretory membrane, with slight 
unilateral swelling located in the right sub-auricular region in the mastoid process of the temporal bone, with no pain sensitivity to palpation, was of a floating consistency, and with a fistula with a mucopurulent exudate (DI FILIPPO et al., 2004; PEIXOTO et al., 2016; PENSE; WILESWSKI, 2002;).

The heterotopic polyodontia developmental location has been reported mainly in the temporal region close to the ear (DI FILIPPO et al., 2004; PEIXOTO et al., 2016; ROCHA et al., 2014) as described in the present case. However, McClure et al. (1993) reported the case of a horse presenting with unilateral nasal secretion diagnosed with heterotopic polyodontia in the ventral conchal region of the paranasal sinus.

The diagnosis of heterotopic polyodontia in this case was based on physical, x-ray, ultrasound, and histopathological examinations. X-ray examination allowed the observation of a rounded and radiopaque structure located near the right temporal bone, as described by McClure et al. (1993) and Gibbs (2005). Similar to in the study by Peixoto et al. (2016), the ultrasound showed a cystic structure measuring $1.21 \times 1.02 \mathrm{~cm}$ in length, presenting hypoechogenic fluid and a hyperechogenic structure in its center (PEIXOTO et al., 2016). The x-ray and ultrasound exams of the case in question did not show the evidence of a tooth-like structure, suggesting the diagnosis of cystic formation. As described in literature, clinical, ultrasound and x-ray examinations do not differentiate heterotopic polyodontia from abscesses, perforating foreign bodies, traumatic bone fragments and dental lesions (GIBBS, 2005; PEIXOTO et al., 2016).

Macroscopic examination revealed a cyst that did not adhere to the temporal bone, with a solid fragment inside, which visually was unlike a tooth. However, according to literature, the crown or root of the tooth, rudimentary or malformed teeth, and even complete dental structures can be found (MCGAVIN; ZACHARY, 2009). According to Gaughan and DeBowes (1993), these structures may vary in amount and size and can be found loosely attached to the soft tissue of the cystic wall or firmly attached to the temporal bone.

A definitive diagnosis is made through histological analysis of the cyst found (EASLEY; FRANKLIN; ADAMS, 2010; JUBB; KENNEDY, 2007). In the present case, the material removed at surgery had a cyst covered by stratified squamous epithelium with a lympho-histio-plasmacytic infiltrate in the dermis as described by Jubb et al. (2007). Similar histopathological findings were described by Peixoto et al. (2016) and McClure et al. (1993), which were consistent with heterotopic polyodontia.

In the present report, clinical treatment prior to hospitalization with antibiotics and anti-inflammatory medication did not promote improvement of the condition; a similar result was found by (MAIA et al., 2004). Thus, in this case, therapeutic resolution was achieved through surgical treatment, similar to that by Di Filippo et al. (2004) who reported that surgical treatment is the treatment of choice, consisting of resection of all dental and cystic epithelial elements, and that incomplete removal could result in the formation of a new fistula.

Surgery is performed electively, but perioperative care is necessary to avoid complications such as damage to the external auditory meatus structures, temporal bone fractures, (HUNT; ALLEN; MUELLER, 1991; JUBB; KENNEDY, 2007) and lesions of the rostral auricular artery, auriculopalpebral nerve, and auricular muscle (FESSLER, 1988; JUBB; KENNEDY, 2007). In this case there were no complications during and/or after the surgical procedure. Duarte et al. (2008) and Prado et al. (2017) reported that after surgical removal of the dentigerous cyst there was facial nerve commitment and the horse temporarily developed left palpebral, auricular and labial ptosis.

Di Filippo et al. (2004) recommends healing by first intention, however, in the case in question due to the presence of contamination, it was decided to leave the wound open for the healing to occur in a secondary. In the postoperative period there were no neuromotor sequelae and wound healing evolved positively. Similar to Gaughan and DeBowes (1993) and Rocha et al. (2014), the surgical procedure has some risks and limitations, but was considered simple, minimally invasive, and had a favorable prognosis.

\section{Conclusion}

Complementary exams such as radiography and ultrasound were important for clinical resolution of the case and the institution of treatment, but the definitive diagnosis of heterotopic polyodontia was only possible after histopathological examination of the removed tissue. The treatment employed was surgical removal of all dental and cystic epithelial elements, promoting the therapeutic resolution of the case in question.

\section{References}

BAXTER, C. J. K. Bilateral mandibular dentigerous cysts in a dog. Journal of Small Animal Practice, v. 45, p. 210 212, 2004.

DI FILIPPO, P. A. et al. Poliodontia heterotopica em cavalos: cinco casos (2002-2003). Brazilian Journal of Veterinary Research and Animal Science, v.41, 2004.

DUARTE, C. A. et al. Paralisia facial em equino após extração de cisto dentígero bilateral: relato de caso. Arquivo Brasileiro de Medicina Veterinária e Zootecnia, v. 15, p. 246-250, 2008.

EASLEY, J. T.; FRANKLIN, R. P.; ADAMS, A. Surgical excision of a dentigerous cyst containing two dental structures. Equine Veterinary Education, v. 22, p. 275 278,2010

FESSLER, J. F. Heterotopic polyodontia in horses: nine cases (1969-1986). Journal of the American Veterinary Medical Association, v. 192, p. 535-538, 1988.

GARDNER, D. G. Dentigerous cysts in animals. Oral Surgery, Oral Medicine, Oral Pathology and Oral Radiology, v. 75, p. 348-352, 1993.

GAUGHAN, R.; DEBOWES, M. Congenital diseases of the equine head. Veterinary Clinics of North America, v. 9, p. 
93-110, 1993.

GIBBS, C. Dental imaging. In: BAKER G.J. \& EASLEY

J. (Eds), Equine Dentistry. 2th ed. Elsevier Saunders:

London, p.171-202, 2005.

HUNT, R. J.; ALLEN, D.; MUELLER, P. O. Intracranial trauma associated with extraction of a temporal Ear tooth. The Cornell Veterinarian, v. 81, p. 103-108, 1991.

JENA, A.K. et al. Orthodontic assisted tooth eruption in a dentigerous cyst: a case report. Journal of Clinical Pediatric Dentistry, v. 5, p. 29-33, 2004.

JUBB, K. V. F.; KENNEDY, P. C. Pathology of domestic animals. 5th edn., Academic Press, New York: p. 6-7, 2007.

MAIA, J.Z. et al. Retirada cirúrgica de um cisto dentígero (odontoma) em um equino (Equus caballus) - Relato de Caso. Veterinária em Foco Canoas, v. 2, p. 67-71, 2004.

MCCLURE, S. R.; SCHUMACHER, J.; EARL, M. Dentigerous cyst in the ventral conchal sinus of a horse. Veterinary Radiology \& Ultrasound, v. 34, p. 334-335, 1993.

MCGAVIN, M. D.; ZACHARY, J. F. Bases da patologia em veterinária. $4^{\mathrm{a}}$ ed. Elsevier: Rio de Janeiro; 1496, 2009.

PEIXOTO, T. C. et al. Cisto dentígero (Polidontia Heterotópica) em equino - Relato de caso. Revista Brasileira de Medicina Veterinária, v. 38, p. 139-142, 2016.

PENCE, P.; WILEWSKI, K. Newborn, weanling, and adolescent horse dentistry. In: Equine dentristry: a pratical guide. Baltimore: Lippincot Williams \& Wilkins, p. 115-139, 2002.

PRADO, T. F. et al. Cisto dentígero em equino. Revista Acadêmica de Ciência Animal, v. 15, p. 251-252, 2017.

ROCHA, L. L. Exérese cirúrgica de um cisto dentígero realizada a campo em potro da raça mangalarga machador relato de caso. Ciência Veterinária nos Trópicos, v. 17, n. 3, p. 64, 2014.

SANTANA, N.M.; REBELLATO, N.L.B.; MACHADO, M.A.N. Divergências de Tratamento do Cisto Dentígero: Revisão Sistematica. Revista de Cirurgia e Traumatologia Buco Maxilo Facial, v. 12, p. 85-92, 2012.

THATCHER, G. Oral surgery: treatment of a dentigerous cyst in a dog. Journal of Veterinary Science, v. 58, p. 195199, 2017.

UZAL, F. A.; PLATTNER, B. L.; HOSTETTER, J. M. Alimentary system. In: Jubb, Kennedy and Palmer's pathology of domestic animals. 6th ed. Elsevier Saunders, Philadelphia, 6-7. 2016. 